\title{
THE ANAL YSIS OF SKIMMING AND SCANNING TECHNIQUE TO IMPROVE STUDENTS IN TEACHING READING COMPREHENSION
}

\author{
Intan Rani Aritonang ${ }^{1}$, Sandi Lasmana ${ }^{2}$, Deti Kurnia ${ }^{3}$ \\ ${ }^{1}$ IKIP SILIWANGI \\ ${ }^{2}$ IKIP SILIWANGI \\ ${ }^{3}$ IKIP SILIWANGI \\ 1intanrani aritonang01@gmail.com, ${ }^{2}$ sandylasmana94@gmail.com,
}

\begin{abstract}
This research deals with The Analysis of Skimming and Scanning Technique to Improve Students Teaching Reading Comprehension. This research explores the implementation of Skimming and Scanning in reading comprehension and to find out the advantages and disadvantages of skimming and scanning used in learning process. The objective of this research is to find out the effectiveness of skimming and scanning strategy in improving students reading comprehension. Data collection technique focus on participant observation, interviews, and documentation. Skimming and Scanning is the appropriate technique to find the main idea, key word and content of the text without read the whole of the text.
\end{abstract}

Keywords: Reading Comprehension, Skimming and Scanning Technique.

\section{INTRODUCTION}

Reading is very important to get information in the world. Reading can make people to know from nothing to something. In English, reading is one of English skill besides listening, speaking and writing. Reading holds the in our life to search information or knowledge from textbooks, article or magazines written in English. Thus, the students should have good reading skills to help them in academic studies and to get information in the world. According to Patel and Jain (2008:113-114), Reading is important activity in life which one can update the knowledge or reading is not only a source of information and a pleasurable activity but also as a means of consolidating and extending one' knowledge of the language. The skill of reading is developed in societies with literary taste, because it can lead to develop comprehension, enrich vocabulary.

The problem of the students in reading skill is comprehension. They difficult to understand meaning of the text and they cannot focus on what they read during the reading activity and still have difficulty to get purpose of the text. The another problem is that not every detail of information in the passage is needed to answer the reading questions but students usually read the reading passage word by word.

Reading is important for students to study reading text in class in order to find out such things as the way use language, the number of paragraphs they contain and how many times they use relative clauses. We must give the students a chance to respond to that message in some way especially they should be allowed to show their feelings about the topic and provoking personal engagement in language.

How well, the students are able to deal with reading material will depend on whether the text are designed for intensive or extensive reading. The term intensive reading refers to reading 
which students do often away from the classroom and intensive reading refers to the detailed focus on the construction of reading text with take place usually in classrooms.

Harmer (2007:100) states students need to be able to do a number of things with a reading text. They need to be able to scan the text particular bits information they are searching for and students also need to skim a text as if they were casting their eyes over its surface to get a general idea of what it is the topic and conclusions. Besides the that reason, another thinks that makes researcher interested in conducting this research is the research of a qualitative research to found of successful in implementing skimming and scanning strategies in teaching reading narrative text.

Therefore, the researcher want to share skimming and scanning to improve students' reading comprehension and to try to gather all the details at the stage and to identify the general idea to concentrating too hard and specifics and previous research related to reading comprehension. This research is going to establish how the effectiveness of skimming and scanning technique in reading classroom. Skimming and Scanning is the technique or strategies to help students comprehending a text, getting detailed information and other reading task.

\section{Definition of Reading}

Reading is part of language skills that important to learn by student because reading could help student to get many information. According to Hill (2000:65) has stated that reading what the reader does to get the meaning students need from textual sources and reading as the process of acquiring and author's meaning and interpreting, evaluating, and effecting upon meanings. And the other expert has argues that reading "as an enjoyable, intensive, private activity, from which much pleasure can be derived, and in which one can become totally absorbed." (Alderson, 2000:13)

\section{Definition of Reading Comprehension}

Reading comprehension is how to get information in the reading students have understanding or comprehend the content of the subject that students read. According to Indrayani (2014) has stated that reading comprehension as the process to get precise understanding of the writer's message trough simultaneously extracting and constructing meaning by collaborating reader's background knowledge and interaction and involvement.

Reading comprehension is not just a receptive process, it implies a complex process in which the reader identify basic information and are able to predict, to infer, to argue, and to recognize writers' points of view. According to Partnership (2005) cited in Diaz, S \&Laguado, J (2013:137), reading comprehension is about understanding a text which is read through the process of constructing meaning from a text.

Lems (2010:170) was also stated that reading comprehension is not a static competency. And Ahuja (2001 in Mohammad, 1999:27) mention that there are three levels of comprehension. The first level is literal comprehension. Comprehension of this level involves surface meanings. At this level, the students can be asked to find information and ideas that are explicitly stated in the text. The second level is interpretive or referential comprehension, at this level students go beyond what is said and read for deeper meanings. They must be able to read critically and analyze carefully what they have read. This level includes thinking process such as drawing conclusions, making generalizations and predicting outcomes. Finally, the third level of comprehension is critical reading where by ideas and information are evaluated. At this level, the teacher can test student's ability to differentiate between fact and opinion, the ability to recognize persuasive statements, and the ability to judge the accuracy of the information given in the text. (Apsari, 2017:36). 


\section{Definition of Scanning and Skimming}

Scanning and Skimming are part of reading skill, Harmer (2007: 100-101) stated that:

a. Scanning

For Particular bits of information they are searching for (as, for example, when we look a telephone number, what's on television at a certain time or search quickly through and article looking for a name or other detail). This skill means that they do not have to read every word and line; on the contrary, such an approach would stop them scanning successfully.

According to Maxwell(1970) in Diaz, S \&Laguado, J (2013:138) states with this scanning, the students look for specific information within a text such as dates, names, places, among others and to defined as the ability to locate specific facts and details quickly, is regarded as a desirable reading skill and is taught in most development reading courses.

\section{b. Skimming}

They were casting their eyes over its surface - to get a general idea of what it is about (as, for example, when we run our eyes over a film review to see what the film is about and what the reviewer thought about it, or when we look quickly at a report to get a feel for the topic and what its conclusion are). This skill means they will get bogged down and may not be able to identify the general idea because they are concentrating too hard on specifics.

According to Maxwell (1969) cited in Diaz, S \&Laguado, J (2013:138), skimming as getting the main idea or gist of a selection quickly in a written text where the student develop powers of inference through systematic practice which encourages them to anticipate of a text. So, skimming can help the students to find the key words that permit them to infer the general sense of a text to interpret text faster and advance the reading process.

\section{The advantages of Scanning and Skimming.}

a. The advantage of Skimming

There are some advantages skimming and scanning building on Grellet (1981:19) in Winarti (2010:15), there are as follow:

a. Skimming can help the students go through the reading material quickly in order to get gist of the text.

b. Skimming help the students to know the text is organized.

c. Skimming can help the students to get an idea of the tone or the intonation of the writer.

It means that, by reading using skimming the students can make reading material easier and students to know how the text is organized and the students can improving an idea of the tone or the intonation of the writer.

b. The advantage of the Scanning

There are some advantages of scanning. There as follow:

a. Scanning help the students only try to locate specific information.

b. Scanning help the students to follow the linearity of the passage.

c. Scanning help the students to used the time efficiently.

Based on the statement above, reading using scanning can help the students to get information from the book and the students can used the time efficiently.

\section{METHOD}

\section{Research Method}

The present study is qualitative in nature. By qualitative research, the data gained will be analyzed in a descriptive ways to explore their attitudes, behavior and experience (Dawson, 
2009) cited in Apsari\&Haryudin (2017). It concerns a detailed description of situation. The data are collected in natural setting without being manipulated.

In qualitative research and qualitative studies the main instrument is the researcher him or herself. The researcher observes, takes notes, talks to people, etc. All of these are skills that need to be learned. As Delamont (2094) wrote : "the biggest problem novices find when preparing for ethnographic field work is that the method books are not explicit enough about what to observe, how to observe and what to write down". The same applies to carrying out interviews. Just the fact that we talk to people in our everyday life, listen, ask questions and communicate does not make us naturally a good interview. According to Helfferich (2009), a good interviewer needs the following skills: technical competence, interactive competence: attention and steering, competencies in communication theory and knowing how to deal with previous knowledge and personal bias.

\section{Instrument or the research}

According to Sugiyono (2010:223) cited in Rakhman and Syatroh (2015:76) states that "the instrument of choice in naturalistic inquiry is the human. We shall she that other form of instrumentation maybe used in later phases of the inquiry, but the human is the initial and continuing mainstay. But if the human instrument has been used extensively in earlier stages of inquiry, so that an instrument has can be constructed that is grounded in the data that human instrument has product.

\section{Time and Place}

The researcher conducted the research on SMK Kharisma Nusantara Tegalwaru, and this research was conducted from $06^{\text {th }}, 13^{\text {th }}$ and $20^{\text {th }}$ of February 2018.

\section{Data Collection and Analysis}

\section{a. Data Collection}

The data was collected by interview, observation, and visual analysis. According to Kaswan and Suprijadi (2016:102) there are many variants of qualitative research involving many form of data analysis, including interview transcript, field notes, conversational analysis visual data, whether photographs, film, or observations of internet occurrences (for the purpose of brevity, this entry calls all of these foms of data text).

b. Data Analysis

In qualitative research, data obtained from various sources, using data collection techniques and continuously conducted until data are collected (Sugiyono, 2010:243) in (Rakhman and Syatroh, 2015:77). There are some processes in analysis data such as: observation, and interviewing the English teacher that used skimming and scanning in teaching English on the part of reading.

\section{RESULTS AND DISCUSSION}

\section{Result}

In this session discuss data analysis and research finding based on data collection used in this research such as observation and interview.

1. Teaching and learning process

The first meet we observation with English teacher of SMK Kharisma Nusantara to find out the reading comprehension students' achievement and analyzing before used skimming and scanning teaching. And the result all of them we found that the student of SMK Kharisma Nusantara still lack of the comprehension which they read. 
And the second meet the teacher prepare to skimming and scanning technique teaching, the first activities the teacher explain the procedures of skimming and scanning techniques.

\section{a. Skimming}

According to John Langan( 1992:394), there are 4 steps to follow in the skimming for the main ideas as followed:

1. Find definition. They are often signaled by special type, especially italics.

2. Located enumerations. It does not help to locate a numbered series of items if you do not know what label the series fits under.

3. Look for relationship between headings and subheadings. Such relationship are often the key paragraphs.

4. Look for emphasis words and main ideas. Look for points marked by emphasis words and main ideas in what seem to be key paragraphs.

\section{b. Scanning}

From the educational website p.32, the steps to do scanning are as followed:

1. Knowing your text well is important. Make a prediction about where in a chapter you might find the word, fact, and date.

2. Note how the information is arranged on a page. Is information arranged alphabetically or numerically?

3. Move your eyes vertically or diagonally down the page, letting them dart quickly from side to side and keeping in mind the exact type of information that you want.

4. Aim for $100 \%$ accuracy.

(http://www.hpcdsb.edu.on.ca/curriculum/literacy//think_literacy_teacher_resource/Think\%2 OLiteracy\%Reading\%20Stra.pdf).

And after explain the procedures the second activities the teacher shared the text to the students and the teacher asked students to read the text used skim and scan technique with the short time, teacher and to motivate students in the read teacher always said "quickly, quickly" so students finished their read the right time.

\section{Discussion}

The observation, students still difficulty in the define of the main idea and the content of the text, after doing skimming and scanning technique teaching, students could answered when the teacher asked students "What is the main idea of the text?" and they answers "Borobudur temple is one of the most beautiful tourist resorts in Indonesia". And it is the correct answer, because the text told about Borobudur temple, and they also knew the content of the text when teacher asked they, it show that skimming and scanning are alternative ways to teaching reading comprehension, and by students interview they like skimming and scanning technique in the teaching reading comprehension because it shall help they to easily in the answer the test with used multiple choice form, they will answer the question quickly.

The teacher answer on the interview, he stated that skimming and scanning technique are one of the best teaching technique in reading comprehension teaching, and it can be used to the students in answering nation exam in reading in reading part.

\section{CONCLUSION}

Reading is important activity in life which one can update the knowledge or reading is not only a source of information and a pleasurable activity but also as a means of consolidating and extending one knowledge of the language. The skill of reading is developed in societies with literacy taste, enrich vocabulary. According to Patten and Jain (2008:113-114), reading comprehension is how to get information in the reading students have understanding or 
comprehend the content of the subject that students read and in indrayani (2014) has stated that reading comprehension as the process to get precise understanding of the writer's message trough simultaneously extracting and constructing meaning by collaborating reader's background knowledge and interaction and involvement.

Harmer (2017:100) states that students need to be able to do a number of things with a reading text. They need to be able to scan the text particular bits information they are searching for and students also need to skim a text as if they were casting their eyes over its surface to get a general of what it is the topic and conclusion. Therefore we need research of a qualitative research to found to successful in implementing skimming and scanning strategies in teaching reading narrative text.Accordingly, this research aims to share skimming and scanning to improve students' reading comprehension and to try to gather all the details at the stage and to identify the general idea to concentrating too hard and specific and previous research related to reading comprehension. This research is going to establish how the effectiveness skimming and scanning technique in reading classroom

Based on research result, several conclusions from the findings are drawn as follows: firstly, regarding to technique used by then teacher the data from observation and interview, the English teacher that use skimming and scanning in teaching English on the part of reading. The last, the result concerning the way implementing skimming and scanning, finding relevant that respondents used the different when the observation, students still difficulty in the define of the main idea and the content of the text, after doing skimming and scanning technique teaching, students could answered when the teacher asked students "what is the main idea of the text?" And they answered "borobudur" temple is one of the most beautiful tourist resorts in Indonesia" . And it is the correct answer, because the text told about borobudur temple and they also knew the content of the text when teacher asked they, it show that skimming and scanning are alternative ways to teaching reading comprehension, and by the students interview they like skimming and scanning technique in the teaching reading comprehension because it shall help they to easy in the answer the test with used multiple choice form, they will answer the question quickly.

\section{REFERENCES}

Alderson, Charles J, 2000. Assessing Reading. Cambridge: Cambridge University Press.

Apsari Y, Haryudin A. 2017. The Analysis of English Lecture's Classroom-based Reading Assessment to Improve Students Reading Comprehension.ELTIN Journal, Vol.5/1.

Diaz, Sindy\&Laguado J. C. 2013. Improving Reading Skills through Skimming and Scanning Techniques at a Public School: Action Research. Open Writing Doors, (online), Vol. 10, No 1.

Hill L. Walter, 2000. Contextual Teaching and Learning. Bandung: MLC

Indrayani, S.A, 2014. The Effectiveness of Using Mind Mapping in improving students Reading Comprehension of Narrative Text. UIN SyarifHidayatullah, The Department of English Education Faculty of Tarbiyah and Teachers Training, Jakarta.

Kaswan, Suprijadi. 2016. English Research Methodology. Putra Praktisi Bandung.

Lems, Kristin et al. Teaching Reading to English Languages Learners insight from Linguistics. New York, The Guildford Press 2010.

Harmer J. 2007. How to Teach English, New edition. Pearson Education Limited

Rakhman A, Syatroh L. 2015. The Analysis Students Team Achievement Division (STAD)

Used in Learning Practice of Translating and Interpreting. ELTIN journal, Vaolume 3/III, October 2015. 